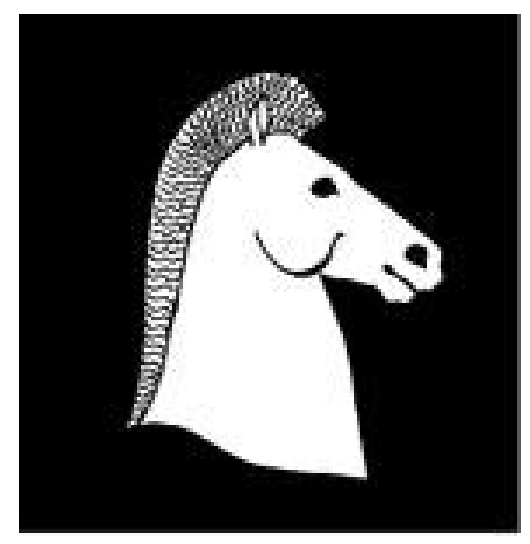

Is Naturalism Bleak? A Reply to Holland and Cottingham

Author(s): IAN JAMES KIDD

Source: Environmental Values, December 2013, Vol. 22, No. 6 (December 2013), pp. 689702

Published by: White Horse Press

Stable URL: https://www.jstor.org/stable/43695104

JSTOR is a not-for-profit service that helps scholars, researchers, and students discover, use, and build upon a wide range of content in a trusted digital archive. We use information technology and tools to increase productivity and facilitate new forms of scholarship. For more information about JSTOR, please contact support@jstor.org.

Your use of the JSTOR archive indicates your acceptance of the Terms \& Conditions of Use, available at https://about.jstor.org/terms 


\title{
Is Naturalism Bleak? A Reply to Holland and Cottingham ${ }^{1}$
}

\author{
IAN JAMES KIDD \\ Department of Philosophy, Durham University \\ 50 Old Elvet, Durham DHI 3HN, UK \\ Email: i.j.kidd@durham.ac.uk
}

\begin{abstract}
Although Cottingham and Holland make a persuasive case for the claim that it is difficult to situate a meaningful life within a Darwinian naturalistic cosmology, this paper argues that their case should be modified in response to the apparent fact that certain persons seem genuinely not to experience the 'bleakness' that they describe. Although certain of these cases will reflect an incomplete appreciation of the existential implications of Darwinian naturalism, at least some of those cases may be genuine. The resulting possibility that certain persons can embrace Darwinian naturalism and live meaningful lives in apparent immunity to the 'bleakness charge' therefore poses new puzzles for Cottingham and Holland, and for wider questions about the meaningfulness of human life. I consider that possibility in light of the work of David E. Cooper and Paul Feyerabend and offer a set of three suggestions for further developing these debates.
\end{abstract}

\section{KEYWORDS}

Cottingham; Holland; bleakness; contingency; existential response; meaning; naturalism.

\section{INTRODUCTION}

In a recent exchange in this journal, John Cottingham and Alan Holland have discussed the moral and existential problems generated by 'Darwinian naturalism'. ${ }^{2}$ Those problems cluster around what one might call the 'bleak-

1. I offer my thanks to Alan Holland and an anonymous journal referee for very helpful comments on this article.

2. See Cottingham 2011 and Holland 2009.

Environmental Values 22 (2013): 689-702.

(C) 2013 The White Horse Press. doi: 10.3197/096327113X13781997646458

Submitted 3 May 2012, accepted 27 June 2012 
ness' charge: that Darwinian naturalism describes a world marked by brute contingency, alienation, and randomness in a way that jeopardises the possibility of one's living a genuinely meaningful life within it. Although their concerns about the 'bleakness' of Darwinian naturalism are well-taken, I argue that certain modifications need to be made to Cottingham's and Holland's accounts of it. Those modifications reflect an important problem for their position, which, stated bluntly, is that not everyone finds Darwinian naturalism 'bleak', and, indeed, some find it positively liberating and wholly capable of sustaining a morally vigorous and deeply meaningful life. My questions, then, are whether those persons are right to reject the bleakness charge, and, if so, what implications that has for Cottingham's and Holland's concerns.

\section{BLEAKNESS - FOR AND AGAINST}

The problem of 'bleakness' is existential in nature. An existential concern is one concerned with issues about the meaningfulness and purposiveness of human life - whether one's own, others or in general. Such concerns arise because human beings are, as David E. Cooper puts it, 'inveterately teleological creatures', necessarily engaged in 'purposive activity, in the pursuit of goals'. ${ }^{3}$ Bleakness arises when one judges that those teleological needs will go unsatisfied, perhaps forever, since the world offers no basis for their satisfaction. For that which is bleak - whether it be a film, a novel or a whole world - provides neither inspiration to engage in meaningful activities, nor a basis upon which to find goals attractive or enticing, nor perhaps any sense of a life being meaningful at all. The deepest sorts of bleakness might even rob a person of their very sense of the possibility of activities and goals being meaningful and purposeful. ${ }^{4} \mathrm{~A}$ person possessed of a deep sense of the bleakness of the world is, as Bernard Williams put it, robbed of that 'motive force which propels him into the future and gives him a reason for living' - hence Cottingham and Holland's strongly evaluative language of alienation, despair and so on. ${ }^{5}$

Such existential responses are, quite clearly, powerful for those who experience them. But the point which concerns me here is that existential responses to Darwinian naturalism vary, quite considerably, and the related suggestion that the 'bleakness charge' ought to incorporate it. Two specific points should be drawn. The first is that certain persons simply do not regard the picture of human beings and the world offered by Darwinian naturalism to be bleak; some find it invigorating and liberating - indeed, one of 'grandeur', as Darwin himself put it. ${ }^{6}$ Understanding those divergent responses is an important task

3. Cooper 2002, p. 261.

4. See Ratcliffe 2012.

5. Williams 1981, p. 13.

6. Darwin 1859 [2009], p. 429.

Environmental Values 22.6 
IS NATURALISM BLEAK?

for those, like Cottingham and Holland, who advance forms of the bleakness charge, and also to wider debates concerning the existential adequacy of naturalism.?

The second is that the fact of divergent existential responses to Darwinian naturalism poses a puzzling question, namely why such very different responses exist and whether they are legitimate or not. This question is less of a puzzle for Holland, for whom 'the conditions for the living of a worthwhile life are really quite minimal', than for Cottingham, who requires more demanding conditions, such as a theistic conviction of the 'ultimate triumph of the good'. My suggestion is that the 'bleakness' which Cottingham and Holland perceive in the Darwinian world-picture is not necessarily shared by all persons, and that consideration of those informed and reflective persons for whom no such sense of impoverishment or 'bleakness' apparently obtains may be instructive.

These two points converge in the idea that differing existential responses to Darwinian naturalism might help us to better understand how and why certain persons can, or indeed can't, find the world, and lives led within it, as meaningful and existentially nourishing. It seems clear that many persons do regard naturalistic cosmologies as 'disenchanting' or 'bleak', for, as David E. Cooper has suggested, a world 'stripped of ... purpose and beauty' may leave us with nothing which could 'serve to guide our activities', for swirling particles and impersonal laws of nature offer no 'measure' by which the meaningfulness of our activities could be determined. ${ }^{9}$ But of course, not everyone regards naturalistic cosmologies in this 'bleak' manner. So for Richard Dawkins, 'this view of life ... bleak and cold though it can seem [affords] deep refreshment', while for the astronomer Margaret Geller, the fact the universe is 'just a physical system' elicits no despair, and she in fact dismisses the question of whether it has a meaning or purpose: '[i]t's not clear that it matters'. ${ }^{10}$

Since I am willing, at least for now, to take them seriously, it seems that the existential responses expressed in the bleakness charge simply do not hold for all persons. Dawkins and other naturalists clearly do not experience the 'bleakness' which Cottingham and Holland report; instead, as they seem to experience something like a 'feeling of awed wonder' and a 'deep aesthetic passion' which, as Dawkins puts it, 'makes life worth living'." Those who share the 'feelings' and 'passions' described by Dawkins are perhaps best described as cheerful naturalists because they are those for whom no sense of bleakness arises, and for whom, indeed, a sense of cheerfulness obtains.

Those feelings and passions are, it seems, sufficient to sustain the needs of these naturalists, as evidenced by Geller's puzzlement at the very idea of

7. See Kidd 2013a.

8. Holland 2011, p. 317.

9. Cooper 2002, p. 56.

10. Dawkins 2004, p. 13. Geller quoted in Lightman and Brawer 1990, p. 340.

11. Dawkins, 2000, p. x.

Environmental Values 22.6 
needing some 'deeper' or 'higher' meaning to the world; in fact it is striking that, for her, the existential question is one which is neither intelligible nor significant. These existential responses are not, I think, peculiar to a few 'hardcore' naturalists, for many persons, it seems, simply do not experience the 'terror' and 'vertigo' which, for John McDowell, should attend the realisation that human beliefs and concepts 'rest on nothing more' than our contingent 'forms of life'. ${ }^{12}$ Certainly many persons $d o$ experience the 'vertigo' which McDowell gestures to, but many others do not, regarding that same fact - of the contingency of our biological nature, moral beliefs and forms of life - with indifference or insouciance. ${ }^{13}$

The great difference between these existential responses to Darwinian naturalism can be brought out by considering them alongside Cottingham's and Holland's remarks on their sense of the 'bleakness' that it generates. Although they disagree on many points, they both agree that the 'world-picture' offered by Darwinian naturalism is characterised by 'bleakness'. So for Cottingham, humans appear as a 'by-product' of the 'vast ... ultimately random unrolling of brute contingency', crawling about within a world lacking 'any ultimate purpose' or, indeed, anything that 'could possibly be redemptive or salvific'. ${ }^{14}$ Similarly for Holland, there is no 'respite from the random' in the Darwinian world, which is 'every bit as random, contingent, remorseless and bleak as Cottingham ... and others describe it to be. ${ }^{15}$ Cottingham and Holland therefore judge that the appropriate response to the 'bleakness' of the world as described by Darwinian naturalism is to seek some compensating belief or project - something 'redemptive or salvific', say - for otherwise one is left with a sense of alienation or despair. Bleakness is, then, for Cottingham and Holland, something that demands some response from human beings, for otherwise their lives will become unbearable.

It is clear enough that Cottingham and Holland are here voicing sincere existential concerns, which are not just abstract technical quandaries about the ontology of value, but rather reflect deep and enduring concerns about the very possibility of one's living a meaningful life within the world as described by Darwinian naturalism. It is, moreover, precisely those concerns which cheerful naturalists, like Dawkins and Geller, do not share, for the sense of bleakness which reflection on them generates for Cottingham and Holland seems not to arise.

12. McDowell 1998, pp. 212 and 207.

13. See Kidd, forthcoming.

14. Cottingham 2011, p. 300.

15. Holland 2009, p. 509.

Environmental Values 22.6 
IS NATURALISM BLEAK?

\section{TWO RESPONSES TO THE CHEERFUL NATURALIST}

The sincerity and depth of Cottingham's and Holland's existential concerns sits in striking contrast with the attitudes of those, like Dawkins and Geller, for who no such concerns obtain. Assuming that they agree on the relevant biological and astrophysical facts, which I'll take it that they do, their responses differ enormously. Cottingham and Holland regard the brute contingencies of our fragile existence in a random universe as an impossibly bleak picture, one which demands response, either by appeal to a theism, for Cottingham, or investing hopes in 'still and small and quiet' things, for Holland. ${ }^{16}$ But those same contingencies and fragilities elicit no such 'vertigo' from Dawkins and other naturalists, who feel that neither the integrity of our moral beliefs nor the meaningfulness of our lives is thus compromised, or even bruised.

Such naturalists - assuming, as I do, that they are sincere - simply do not find themselves called to confront or cope with the existential challenge which Cottingham defines in terms of "contingency, alienation, despair, failure and fragility'. ${ }^{17}$ Since those naturalists are not troubled by the fact of their being 'naked apes' resulting from an aimless evolutionary process, they do not feel alienated from the world and so no sense of bleakness arises. For they do not find themselves robbed of what Williams called that 'motive force' which, for other people, a meaningful life depends. Their cheerfulness, then, is not a stance of tactical optimism but rather a reflection of their being untroubled by the sorts of existential concerns which arise from a sense of bleakness. So this sort of naturalist is cheerful not because they judge it to be the best response to a bad situation, but because they do not feel themselves to be in a bad existential situation at all.

Such naturalists will therefore hardly find the 'bleakness charge' either compelling or perhaps even intelligible - as indeed many do not. Indeed, they will likely regard Holland's worry that Darwinian naturalism compromises 'the very possibility of living a meaningful, and therefore worthwhile, life' as just peculiar, and his talk of the redemptive possibilities - like courageous 'self-affirmation' - as either peculiar or just plain redundant. ${ }^{18}$ The question is therefore whether these existential responses to Darwinian naturalism ought to be taken seriously, and if so, what implications they have for the 'bleakness charge'.

An obvious answer to that question is that those existential responses are, in fact, bogus. Although naturalists like Dawkins and Geller may cheerfully concede the contingency and fragility of our lives - the fact that we're accidental products of a random system - they cannot, in fact, actually maintain that those concessions entail no existential alarm. If they fail to experience

16. Holland 2009, 513 .

17. Cottingham 2011 , p. 300-301 ff. See further Cottingham 2009.

18. Holland 2009, pp. 503 and 516.

Environmental Values 22.6 
the sense of 'vertigo' that McDowell describes, then that indicates, not their defiant existential valour, but, rather, their imperfect understanding of the implications of their beliefs. Those cheerful naturalists are, then, guilty on one of two counts. Either they have failed to properly understand and appreciate the implications of the naturalistic cosmology they have embraced - in which case they are at cognitive fault; or they in fact have, but pretend that those implications don't trouble them, or that they can cope with them. In the first case, the cheerful naturalist is guilty of ignorance, while in the second case they are, as Cooper puts it, guilty of hubris, for they attribute to themselves 'a capacity they do not have', namely of being able to cope with the conviction that their decisions and commitments have 'no further authority than their being the ones we happen to have made'. ${ }^{19}$

Call these two responses to the cheerful naturalist the ignorance and the hubris objections, and let me take each in turn. It might be, in the first case, that when Dawkins and Geller insist that Darwinian naturalism affords 'deep refreshment' rather than bleakness, they are simply ignorant of certain facts about that doctrine; for instance, they may suppose that the 'brute contingency' does not compromise the integrity of our moral values when in fact it does, or they may not be sufficiently conversant of the philosophical complexities of the issues they raise to appreciate the 'bleak' implications of the naturalistic doctrine they cheerfully embrace. The adoption and embrace of cheerful forms of Darwinian naturalism is therefore premised upon an ignorance of the philosophical issues which motivate the bleakness charge, with the corollary that, if that ignorance were dispelled, bleakness would surely follow.

The second response offered by Cooper is cast in terms of what he calls a 'posture of hubris'. A person guilty of adopting a posture of hubris is one who 'aspire[s] to live in the recognition that, ultimately, their beliefs and values "lean on nothing" beyond themselves', and that, in fact, no such external or objective measure is necessary, or perhaps even possible. ${ }^{20}$ Cooper stresses that a person occupying a posture of hubris is 'refusing to ... rely in any way' on something 'that he cannot really do without'. ${ }^{21}$ The cheerful naturalist would be guilty of adopting a posture of hubris, because they pretend to be able to entertain commitments and claims - specifically, that the life they are leading is a meaningful one - which they cannot, in fact, maintain, given the conception of reality they have adopted. By cheerfully insisting that meaningful lives are possible in conjunction with a commitment to Darwinian naturalism, figures like Dawkins and Geller are therefore guilty either of ignorance or of hubris: for they are either ignorant of, or deny, their need for some degree of measure which their metaphysical commitments do not and cannot provide.

19. Cooper 2009, p. 53. Specifically, of what Cooper dubs hubris of posture.

20. Cooper 2002, p. 210.

21. Cooper 2002, p. 163.

Environmental Values 22.6 


\section{IS NATURALISM BLEAK?}

It is worthwhile explaining further how cheerful naturalism invites the charge of postural hubris which Cooper offers. That task can be taken in four parts, each taken from Cooper's own discussion, of which the following account is only a summary. ${ }^{22}$ First, human beings need to find and understand their lives, at least in substantial part, as significant or meaningful. Second, assigning significance to some features or aspects of one's life requires one to identify its 'appropriate connection with', or contribution to, 'something beyond itself' - some wider project or activity in virtue of which its meaningfulness or significance can be determined. To take an easy example, writing an academic paper may be judged valuable in light of the wider project of pursuing philosophical understanding. Third, one must be able to judge how and when these chains of significance stop, without that judgement rendering pointless the activities whose significance was being scrutinised; otherwise the purpose for which those chains were traced is compromised. Fourth, then, Cooper argues that the chain of significance cannot stop within the range of human 'practices, forms of life, traditions [and] personal commitments', for these still admit of the question of their meaningfulness, for they defer it to wider and wider sets of commitments and activities - from one's own philosophical activities, to the activities constitutive of the tradition of philosophy, and so on.

With this argument in place, Cooper insists that the significance of our human practices, values, and activities must lie beyond the human, for whatever remains within the precincts of the human always inspires the question of its own significance. The cheerful naturalist, of course, agrees there is something 'beyond the human', namely the world as described by the natural sciences - including but not limited to biology; however, that is not a conception of reality which can render meaningful or significant human activities, for, to quote Geller again, it is 'just a physical system'. There is therefore no reason for cheerfulness, for the cheerful naturalist who raised the question of the meaningfulness of their activities - whether scientific enquiry, personal friendships or whatever - will find that their 'chains of significance' come to an end in a cosmos which cannot intelligibly be judged to provide the sort of 'measure' that Cooper has in mind.

Instead, that cheerful naturalist is confronted with what Cottingham and Holland - to recall remarks quoted earlier - described as a 'vast ... ultimately random unrolling of brute contingency' which affords no 'respite from the random'. Once this process of philosophical reflection has been completed, the charge of ignorance dissolves, because the cheerful naturalist has been acquainted with the relevant kind and degree of understanding necessary to appreciate the charge of bleakness. But of course, the charge of ignorance is quickly exchanged for the charge of postural hubris, for the cheerful naturalist cannot provide an account of why their activities matter, for to do that, they

22. See Cooper 2002, pp. 266-276 and, further, Cooper 2009. 
IAN JAMES KIDD

require a measure by which to determine the significance of their practices, activities and commitments which their conception of reality cannot provide. Cooper, of course, argues that the cheerful naturalist can do one of two things at this point. Either they can concede their need for some 'compensating' beliefs or convictions - and I leave off discussion of his own complex proposals for what they might $b^{23}$ - or they defiantly deny their need for such compensations, insisting, instead, that they are exempted from the need for it. At that point, they become 'properly' guilty of hubris, for they thereby pretend to possess a capacity - that of living without a 'measure' for the meaningfulness of their commitments - which they in fact lack and which, in fact, no human being does or could possess.

\section{COULD SOME PERSONS COPE WITH BLEAKNESS?}

Considering these thoughts of Cooper's therefore offers two responses to the cheerful naturalist: either they are guilty of ignorance or guilty of hubris. To take Dawkins and Geller as examples, one can therefore argue that either they have failed to realise the existential implications of their commitments, or that they have hubristically supposed that they can cope with them, when, in fact, they cannot.

These two charges between them place the cheerful naturalist in a difficult position. If one presumes that they regard their lives as meaningful - which is plausible enough - then their indifference to the existential worries that Cottingham and Holland raise is a sign of 'bad faith', in Sartre's sense. For if they were to properly reflect on the existential implications of Darwinian naturalism, their confident immunity to the bleakness charge would dissolve, leaving them in the state of 'vertigo' within which one then needs, as Cottingham and Holland point out, to seek some redemptive solution - an embrace of theism, or gentle hopefulness, or whatever.

The charge as it stands, then, is that the cheerful naturalist who disavows the bleakness charge and insists that an awareness of the 'brute contingency' and 'randomness' of the world does not trouble them, is, in fact, either ignorant or imperfectly appreciative of the implications of that awareness. Although the foregoing appeal to Cooper's charge of hubris adds further complications to an already complicated issue, it does, I think, help to clarify what I take to be a deeply important issue concerning the bleakness charge, namely: might it be the case that certain persons are in fact capable of simultaneously finding meaningful their activities and commitments (and indeed their life) while also embracing doctrines like Darwinian naturalism which do not themselves provide any 'measure' for their meaningfulness?

23. See, for instance, Cooper 2002, ch.13.

Environmental Values 22.6 
IS NATURALISM BLEAK?

That rather complex question can be unpacked in the following way. Cottingham and Holland identify the bleakness charge as an important problem for Darwinian naturalism, but of course will likely find it difficult to persuade those who cheerfully deny the charge that there is, in fact, any problem to be had. It is likely, in my judgement, that 'doubters' will fall into one of two camps; first, those who don't find Darwinian naturalism 'bleak' but would if they reflected upon it, and, second, those who don't find it 'bleak' and still wouldn't even after prolonged reflection and deliberation. The first group of 'doubters' are guilty of ignorance and, were they properly availed of relevant understanding, would quickly concede the bleakness charge - thereby also evading the charge of hubris. Such persons may therefore initially report no sense of existential anxiety in the face of Darwinian naturalism, but, of course, an appreciation of bleakness is their rather unpleasant reward for reflecting critically upon its existential implications, if indeed they do.

The second group of 'doubters' are those whom Cooper would charge with hubris. For they are not ignorant of the philosophical concerns motivating the bleakness charge, but insist that they can, in fact, live without any compensating 'measure', thereby embracing, rather than seeking to evade, the charge of hubris. Such defiantly cheerful naturalists are those for whom Darwinian naturalism is, to use Dawkins' term, 'refreshing', rather than bleak, alienating and a cause for existential despair. My question of whether certain persons can simultaneously embrace Darwinian naturalism and still find their lives genuinely meaningful, rather than bleak, is therefore directed at the persons in this second group.

Is it perhaps possible that certain people - these defiantly cheerful naturalists - are, in fact, genuinely immune to a sense of bleakness? These would be persons who accept Darwinian naturalism and come to a reflective appreciation of its existential implications, avail themselves of the relevant philosophical issues, and so on, yet who still, at the end of all of that, genuinely experience no sense of bleakness, 'vertigo', or meaninglessness. Such persons clearly are not guilty of ignorance, although it may be an open question as to whether they are guilty of hubris, of claiming to possess a capacity they lack. It strikes me as overly presumptive to suggest that a person could not, in fact, regard Darwinian naturalism as existentially sufficient, especially since one cannot foreclose the possibility of there being sufficiently informed and reflective persons who might claim to occupy that position. Such persons may be very few in number, but, of course, their rarity would be a proof of, not an argument against, their possibility; the question is, though, whether such existential selfsufficiency is in fact a possibility or not.

Certainly the idea that certain persons are immune to the bleakness charge is an intriguing one, but let me offer just two ways of thinking about that claim. These two proposals are not exhaustive, but are simply offered as ways to go 
about asking and, hopefully, answering that question: let me call them the historicist and the ahistoricist strategies and take each in turn.

The historicist approach to the question of whether certain persons may be immune to bleakness focuses on the possibility of an historical development in human existential capacities. The historicist may be sympathetic to the thought, voiced by Cottingham and Holland, that human flourishing requires a more existentially responsive conception of reality than that of Darwinian naturalism, but they think that there are good reasons to take seriously the idea that, in fact, certain persons do not share that requirement. Nietzsche, of course, took that claim seriously, for his Overman is the legislator of his own 'table of values' and regards the 'death of God' as joyous emancipation. But even less polemical authors, like Charles Taylor, have speculated that the 'modern ... self' is coming to enjoy a 'very different existential condition', one capable of 'disengaging from everything' - from both 'cosmos and God' - and becoming 'master of the meanings of things ... giving [his] own autonomous order to [his] life'. ${ }^{24}$ If this is the case, then the 'bleakness charge' may be a phenomenon of a transitory stage in our history, in which our existential sensibilities are adjusting from predominantly theological cosmologies - of the sort Taylor describes - to the naturalistic ones whose early chorus members may be Dawkins and Geller.

The historicist therefore takes seriously the idea that the charge of hubris is a creature of history, because the 'modern self' whose emergence Taylor documents is, in fact, capable of living without the measure described by Cooper. Such a creature would, as Richard Rorty puts it, genuinely rest content with 'obedience to [their] own conventions' and who, in the words of the novelist Alain Robbe-Grillet, 'no longer feels the absence of meaning as a lack [and] succumbs to no dizziness'. ${ }^{25}$ Those two figures, and their claims, are quoted and discussed by Cooper in the context of his own discussion of the possibility of 'modern selves' freed or liberated from the need for measure - and he is, of course, critical of their claims. Now, not everyone will be persuaded by Cooper's charge of hubris against figures such as Rorty and Robbe-Grillet, nor by his account of our need for 'measure' to protect us against vulnerability to bleakness; however, the historicist claim that, in fact, certain persons may be the beneficiaries of a developing capacity for existential self-sufficiency is worth taking seriously, if only as a new strategy for combating those who claim immunity to bleakness.

The ahistoricist approach is perhaps predictably opposed to any talk of maturing or evolving capacities and powers, interpreting this instead as just the latest stage in longstanding tendencies of human beings, perhaps since antiquity, towards ignorance and hubris. A recent defence of the ahistoricist approach to the purported evolution of our existential responses to naturalistic

24. Taylor 2007, pp. 38-41 passim.

25. Quoted in Cooper 2002, 156-157 and 265, respectively.

Environmental Values 22.6 
IS NATURALISM BLEAK?

cosmologies, such as Darwinian naturalism, was offered by Paul Feyerabend. The title of his final book, Conquest of Abundance, refers to what Feyerabend sees as a historical trend, beginning in ancient Greece, which is resulting in the gradual dissolution of the rich diversity of ways of conceiving of and living within the world evident across human history - magical, theological, scientific and so on. The fact that human beings can, and indeed have, developed these different ways of 'approaching' reality indicates that we are not 'aliens [but rather] natural inhabitants' of the world, capable of living meaningful lives within its 'abundance' - but if only we employ conceptions of reality sufficiently 'responsive' to our existential needs. ${ }^{26}$

Feyerabend shares Cottingham and Holland's concern with the bleakness of naturalistic cosmologies. Many of his later works address the question of how world-pictures - like Darwinian naturalism - which 'reduce abundance and devalue human existence', can become 'powerful [and] plausible', especially given that their consequences have been to render human life 'disorient[ing] ... scattered [and] aimless' ${ }^{27}$ Confident talk of growing immunity to bleakness should, argues Feyerabend, be interpreted in terms of long-standing cultural and intellectual tendencies which erode our existential sensibilities, especially a 'general movement towards abstractness and monotony' which sees the richness and diversity of human experience gradually dissolved, thereby depriving us of 'important ingredients of a rewarding human life' ${ }^{28}$

There is much to consider in Feyerabend's complex historical and philosophical claims about the 'conquest of abundance', which deserves sustained treatment in its own right. It is, however, worth noting just two useful points about it.

The first is its implication that those confident 'modern selves' described by Rorty and Robbe-Grillet are, in fact, ignorant of their status as occupants of a certain historical legacy. 'Even an excessively reflective agent is never fully in control' of their convictions, writes Feyerabend, for they are 'already sailing along with one of the tendencies, which means that her choice will appear to her not as a choice but simply as a step on the road to truth' ${ }^{29}$ Put another way, there is no reason to suppose that cheerful naturalists enjoy a privileged epistemic perspective upon their history - one which justifies their claim to be the beneficiaries of emerging and enriched existential capacities. Indeed, there is hubris in their claim to be able to determine that their cheerful immunity to bleakness is just that - a newly-gained capacity - rather than just the latest example of longer historical tendencies towards ignorance and hubris.

The second point to take from Feyerabend is that reflection on history, whether in terms of his 'conquest of abundance' narrative or not, may temper

26. Feyerabend 2001, pp. 167 and 195. See further Kidd 2013b.

27. Feyerabend 2001 , pp. 16 and 246.

28. Feyerabend 2001 , pp. 198 and 269

29. Feyerabend 2001, p. 85.

Environmental Values 22.6 
confident claims about newly-emerging existential capacities. To take just one example, in his most recent book Cooper discusses humans' relationship to nature, identifying a series of 'moods' - of yearning, nostalgia, disillusion and a feeling for mystery - which accompany the atrophy of our sense of convergence with nature; the sense, for instance, of a lost 'oneness' with nature. ${ }^{30}$ Although those moods are familiar from the literature on contemporary human beings' estrangement from nature, as a result of technology or the disenchantment effected by the scientific worldview, Cooper demonstrates that, in fact, they were also recognised by Daoists from the fifth century BCE onwards. Bleakness is, then, perhaps an enduring feature of human reflection upon the meaningfulness of their lives, rather than a passing phase in the history of those reflections. Indeed, debates about the bleakness of naturalistic cosmologies are hardly the special preserve of late modernity, with its industry and science, but have, perhaps, been enduring features of human beings' efforts to understand the possibility of a meaningful life within the world.

\section{CONCLUSIONS}

The historicist and ahistoricist approaches to the question of whether certain human beings could in fact enjoy a maturing immunity to the bleakness charge offer up large areas of further enquiry. Certainly the remarks offered here, including the appeals to Cooper and Feyerabend, offer problems and possibilities rather than solutions, thereby making the original debate between Cottingham and Holland more, rather than less, difficult. Such worries are, however, occupational hazards of philosophising, but let me close with three suggestions which might aid further discussions. The first is that is the charges of ignorance and hubris offer useful ways of critically engaging with the cheerful naturalist, including new ways of trying to understand their claims about why, if at all, naturalism is not bleak.

The second is the possibility - even if it is only that - of a growing capacity, amongst certain persons at least, for existential self-sufficiency, one becoming visible in the ostensibly hubristic rhetoric of many contemporary figures, like Rorty and Dawkins. If that possibility is a genuine one, it allows for a much greater variety of ways of authentically conceiving of and comporting oneself within the world may be possible than Cottingham and Holland admit. At the least, further understanding of those for whom the 'bleakness charge' does not arise may be instructive for those of us for whom it does.

The third suggestion is the issue at stake in the debate between the historicist and the ahistoricist; namely, of whether persons susceptible to the bleakness charge are, in fact, inheritors of an older set of existential orientations which are destined to take their place alongside, if not be replaced by, the

30. Cooper 2012, p. 12.

\section{Environmental Values 22.6}


IS NATURALISM BLEAK?

'modern self' described by Taylor and others. Whether that would indicate the ongoing atrophy of our sensibilities - as Cooper and Feyerabend believe - or the maturation of our existential self-sufficiency is a topic worthy of further consideration.

\section{REFERENCES}

Cooper, D.E. 2002. The Measure of Things: Humanism, Humility, and Mystery. Oxford: Clarendon Press.

Cooper, D.E. 2009. 'Mystery, world and religion'. In J. Cornwell and M. McGhee (eds.), Philosophers and God: On the Frontiers of Faith and Reason, pp. 51-62. London: Continuum.

Cooper, D.E. 2012. Convergence with Nature: A Daoist Perspective. Dartington: Green Books.

Cottingham, J. 2009. 'The good life and the "radical contingency of the ethical"'. In D. Callcut (ed.), Reading Bernard Williams, pp. 24-42. London: Routledge.

Cottingham, J. 2011. 'Reply to Holland: The meaning of life and Darwinism'. Environmental Values 20: 299-308. CrossRef

Darwin, C. 1859 [2009]. The Origin of Species: By Means of Natural Selection, or the Preservation of Favoured Races in the Struggle for Life, edited by Jim Endersby. Cambridge: Cambridge University Press.

Dawkins, R. 2000. Unweaving The Rainbow: Science, Delusion, and the Appetite for Wonder. New York: Houghton Miffin Harcourt.

Dawkins, R. 2004. A Devil's Chaplain: Reflections on Hope, Lies, Science, and Love. New York: Houghton Mifflin Harcourt.

Feyerabend, P. 2001. Conquest of Abundance: A Tale of Abstraction versus the Richness of Being, edited by B. Terpestra. Chicago: University of Chicago Press.

Holland, A. 2009. 'Darwin and the meaning in life'. Environmental Values 18: 503518. CrossRef

Holland, A. 2011. 'What do we do about bleakness?'. Environmental Values 20: 315321. CrossRef

Kidd, I.J. 2013a. 'A phenomenological challenge to "enlightened secularism"', Religious Studies 49: 377-398.

Kidd, I.J. 2013b. 'Feyerabend on the ineffability of reality'. In A. Kasher and J. Diller (eds.), Models of God and Other Ultimate Realities, pp.849-860. Dordrecht: Kluwer. CrossRef

Kidd, I.J. forthcoming. 'Emotion, religious practice, and cosmopolitan secularism'. Religious Studies.

Lightman, A. and R. Brawer (eds.) 1990. Origins: The Lives and Worlds of Modern Cosmologists. Cambridge, MA: Harvard University Press.

McDowell, J. 1998. Mind, Value, and Reality. Cambridge, Mass.: Harvard University Press. 
702

\section{IAN JAMES KIDD}

Ratcliffe, M. 2012. 'What is it to lose hope?', Phenomenology and the Cognitive Sciences, in press.

Taylor, C. 2007. A Secular Age. Cambridge, Mass.: Harvard University Press.

Williams, B. 1981. Moral Luck. Cambridge: Cambridge University Press.

Environmental Values 22.6 